\title{
The aporia of refugee rights in a time of crises: the role of brokers in accessing refugee protection in transit and at the border
}

Sara Riva ${ }^{1 *}$ and Gerhard Hoffstaedter ${ }^{2}$

* Correspondence: sara.riva@cchs. csic.es

${ }^{1}$ Marie Skłodowska-Curie Research Fellow, Spanish Research Council (CSIC), Madrid, Spain

Full list of author information is available at the end of the article

\begin{abstract}
Many refugees fleeing from persecution across borders, find navigating the refugee registration system extremely complicated. In many border spaces, destination or transit countries, the difficult registration processes and the lack of support services requires the intervention and support of many non-state actors. Over the past decades, neoliberal policies have increasingly relegated public responsibilities to the private sphere. In this vein, a range of organisations have been working with refugees to assist them access to their legal status. This paper seeks to critically examine on-the-ground practices of these individuals, international and local nonprofit organisations_-or brokers - in Malaysia and the United States of America. Using ethnographic fieldwork data from these two very disparate fieldsites-one a signatory of the Protocol to the Convention, the other a non-signatory country-we document shared difficulties, frustrations, opportunities and specific obstacles, strategies and tactics refugees and organisations deploy. Building on Hannah Arendt's insights of an internal contradiction in the human rights framework, we point to a new aporia: Whilst there now exist international instruments to protect refugees, access to this framework and its protections is becoming ever more challenging. This means that those seeking asylum need the assistance and mediation of third-party organisations in order to access their rights. The struggle for recognition and protection thus is no longer about achieving universal rights, but rather on how vulnerable populations can access them.
\end{abstract}

( ) The Author(s). 2022, corrected publication 2022. Open Access This article is licensed under a Creative Commons Attribution 4.0 International License, which permits use, sharing, adaptation, distribution and reproduction in any medium or format, as long as you give appropriate credit to the original author(s) and the source, provide a link to the Creative Commons licence, and indicate if changes were made. The images or other third party material in this article are included in the article's Creative Commons licence, unless indicated otherwise in a credit line to the material. If material is not included in the article's Creative Commons licence and your intended use is not permitted by statutory regulation or exceeds the permitted use, you will need to obtain permission directly from the copyright holder. To view a copy of this licence, visit http://creativecommons.org/licenses/by/4.0/. 
A refugee is a person who fits the definition dictated by the 1951 UN Refugee Convention or its 1967 Protocol. ${ }^{1}$ Refugee registration is mandated by the Convention and signatory states design their own refugee status determination processes, whilst others rely on the office of the United Nations High Commissioner for Refugees (UNHCR) for registration processes. Seventy years ago, Hannah Arendt (Arendt 1979) pointed to an aporia within human rights obligations: "precisely when the stateless appeared as nothing more than human, it proved very difficult, if not impossible, for them to claim the allegedly inalienable rights they were entitled to by virtue of being born human" (Gündoğdu 2012, p. 4). Arendt's critique of the Universal Declaration of Human Rights was based on her experiences of the failure of global or universalising rights regimes that had to be enforced or abided by (nation) states. This disconnect between the state's duty of care towards its citizens versus a rights regime that is based on universals and encompasses all people continues to haunt us. In order to better deal with stateless people and those forced to leave their country due to persecution, the international community came together to create a global refugee rights regime that would provide safeguard even when individual nation-states withdrew protection. The Convention and Protocol Relating to the Status of Refugees are the international legal frameworks that have endured to this day to achieve this. Likewise, the creation of the UNHCR in 1950 allowed for an international organisation to operate globally to protect refugees and support national refugee registration and protection regimes. Whilst some argue that the right to have rights is really an issue of having a right to enter a country (Hirsch and Bell 2017) in order to gain access to inalienable human rights, we show that mere access to territory is not enough. Accessing refugee rights is no longer a problem of jurisdiction but one of enforcement. Even though there are international treaties in place that protect those who seek asylum, for most people fleeing from persecution across borders, navigating the varied refugee registration systems is an extremely difficult task. Additionally, the implementation of neoliberal policies by most countries have enabled the transfer of public functions to private actors leaving a gap within the refugee regime that is not met by the state but by non-state actors. The lack of government or UNHCR support services has required the intervention and support of international and local organisations, as well as other actors, to intervene as mediators-or brokers-for those who seek asylum in accessing their rights.

This paper seeks to critically examine on-the-ground practices of these international and local non-profit organisations in Malaysia and the United States of America that act as brokers. Using fieldwork data from these two very disparate fieldsites-one being a signatory of the Protocol to the Convention, the other a non-signatory country-documents shared difficulties, frustrations and opportunities as well as specific obstacles, strategies and tactics refugees and organisations deploy. This article builds on Arendt's insights and we point to a new aporia: Whilst there now exists a wider recognition and global legal framework to protect refugees, access to this framework and its protections is increasingly made difficult. This means that those seeking asylum increasingly need

\footnotetext{
${ }^{1}$ Both asylum-seekers and refugees seek protection of a state, the difference is the legal determination of status. Referring to the people we talk about as a "refugee" or as an "asylum-seeker" reinforces the idea that the former genuinely needs protection while the latter doesn't. Thus, in this paper, we follow former Assistant High Commissioner (Protection) for UNHCR, Ms. Erika Feller seeing asylum seekers as "unregistered refugees" who have not yet been officially recognized as refugees (see Hoffstaedter 2015a, 3).
} 
the assistance and mediation of a third-party organisation in order to access their rights. The struggle for recognition and protection thus is no longer about achieving enforceable universal rights, but rather on how vulnerable populations can access them. By drawing on comparative ethnographic research, this article seeks to address a gap in the literature regarding the role of local and international organisations as brokers in the refugee regime.

\section{Methodology}

This article was prompted by a conversation about our fieldwork experiences. We realised that refugees in different parts of the world share a very common issue: the difficulty of accessing their legal status. Sara described how she had worked with an organisation in the United States border that helped refugees access their rights. While Gerhard narrated how the involvement of different organisations in Malaysia was key for those who seek to attain refugee status through the UNHCR. We both acknowledged that neoliberalism had played a key role in enabling non-state actors to access refugee management. This is more evident in countries where neoliberal policies are more salient, such as the United States. Additionally, our distinct research fields illuminated the numerous critiques of the Refugee Convention. In both our cases, those seeking asylum do not comply with the original image the Refugee Convention had in mind of a middle-class educated white male. Sara's experience in the field highlighted how the intersection of class and gender was a relevant aspect that played into the complexity of the refugee system: women who cross the US Southern border are racialized and stigmatized through deviant narratives. While Gerhard emphasised how the intersection of class and ethnicity acted as salient dimensions the UNHCR and community refugee registration processes. In both cases language constituted a tremendous barrier for those seeking asylum. However, in the US case, the staff of the organisation that acted as a broker could translate the whole process for the detained women. While in the Malaysian case translators are provided by the UNHCR, many experiences depict a sometimes chaotic and haphazard approach. Even though at first sight the comparison of these two fieldsites might have seem uncanny, we were struck by the similarities our findings shared. We found that putting both cases side by side-each with its particularities-sheds light on the major role that brokers play within the current global refugee regime.

This paper is the result of ethnographic fieldwork conducted in the two abovementioned distinct places of irregular migration. Sara conducted research in 2016 when she spent nine months traveling back and forth to a US family immigration detention centre at the Southern border volunteering for a non-profit organisation. Gerhard conducted fieldwork in 2015-2016 over a 12-month period in peninsular Malaysia working with refugees and community refugee organisations (CROs) predominantly in and around Kuala Lumpur. As researchers, we are aware that knowledge is always situated (Haraway 1988), and thus we want to clarify our positionality during our fieldwork.

While Sara was conducting research at a US family immigration detention centre, she was also working in the NGO as-what we later define-a broker, helping refugees access their rights. This humanitarian organisation working in the detention centre was formed by legal advocates, a category that includes all personnel and volunteers. The family immigration facility where Sara conducted research is owned and managed by a 
private prison corporation-CoreCivic (formerly Corrections Corporations of America). However, the vast majority of the legal advocates who work in that space offer their services on a purely pro bono volunteer basis and the NGO is not contractually engaged or otherwise obliged by the government to offer their aid to refugees. Working alongside legal advocates helped enrich the ethnographic material of the research. This methodology_combining "advocacy work with ethnographic fieldwork" (Cabot 2013, p. 455; Coutin 2007) -allowed for the opportunity to build personal relations with the legal advocates, as well as build greater awareness of the challenges these brokers face while working with confined populations -in this case, women and children. Gerhard conducted research in several refugee communities in Malaysia. As an engaged anthropologist, he worked with refugee organisations and individuals to better access services and the UNHCR registration process at times-precisely the work of brokers we detail below. However, the emphasis was always on enhancing existing capacity, rather than replacing or circumventing it, although on occasion this did happen to assist very vulnerable refugee applicants get access to the UNHCR or critical information from UNHCR.

For our research, we used participant observation and semi-structured interviews that allow for more open-ended questions. The interview method was a good entry point to elucidate the connection between practices and discourses-or how practices get shaped by discourse. This approach was complemented by participatory observation and a critical engagement with secondary literature. Such methodologies enabled the understanding of the daily lived experiences of brokers, and the everyday realities of processes in accessing legal status. Long-term ethnographic research helped us grasp the roles brokers play in the current refugee processing regime. By focusing on two distinct cases-Central American women who seek asylum in the United States and are confined in immigration detention centres within US territory; and Rohingya from Myanmar who seek asylum in Malaysia-we seek to establish the transnational connections that evidence the very similar challenges that refugee populations face in different parts of the world when they are trying to access their legal status.

\section{Refugees: Arendt, rhetoric and rights}

Hanna Arendt wrote The Origins of Totalitarianism (1979 [1951]) in the aftermath of the second World War. In it, she finds a fundamental aporia-internal contradictionin human rights. Since, at that time, human rights were connected to fundamental characteristics of the European nation-state system, those who were stateless could not access even the so-called "universal" human rights. Nation-states remain based upon territorial integrity as well as specific national identities (Xenos 1993), and human rights were only guaranteed as national rights within national constitutional or legal arrangements. Therefore, nations only protected those with the same national origin, excluding and making rightless many members of national minorities-or stateless people. $^{2}$ Arendt builds her critique upon this contradiction and claims that the most basic human right should be "the right to have rights" (Arendt 1979, 296). This a priori right is fundamental as all supplementary human rights can only flow from the right to

${ }^{2}$ According to the Convention Relating to the Status of Stateless Persons (1954), the legal definition of statelessness means: "a person who is not considered as a national by any State under the operation of its law". 
have rights. Arendt states that refugees, like stateless people, are caught up in a situation where they do not have the protection from their respective countries, nor do they belong to the country they flee to. In this regard, Arendt argues, stateless people and refugees are deprived of basic protections usually afforded by citizenship.

Refugees today continue to be bereft of these basic protections in many places of the world, where they can only access their rights with the help of others, usually local or international organisations or individuals acting as brokers. Accessing refugee rights is no longer a problem of jurisdiction-since many refugee-receiving countries are signatories of the Convention or the Protocol-but one of enforcement. In our cases, we find that there are two possible reasons for the disconnect between the human rights discourse and its on-the-ground practices-or rather, how refugees can access those rights. First, international law is not enforced or enforceable. Today, even signatories to international conventions violate their own human rights laws (see for instance Grewcock 2013 on Australia). Second, there is a lack of interest from many countries to give refugees access to their rights. A significant part of this is due to the xenophobic politics of fear rhetoric that depicts immigrants and refugees as a threat to society.

In this vein, the narrative often revolves around the protection of the nation from "outsiders," who allegedly take advantage of the "system," are deemed a threat to national security, have too many children, contaminate the dominant national culture, and so on. These discourses mirror the one used by Nazi propaganda in their SS official newspaper to describe the "undesirables" of the German Reich, such as Jews and Trotskyites. Arendt (1979) claims that "the Schwarze Korps [official newspaper of the SS], stated explicitly in 1938 that if the world was not yet convinced that the Jews were the scum of the earth, it soon would be when unidentifiable beggars, without nationality, without money, and without passports crossed their frontiers" (269). Today, media images and discourse still associate foreigners with notions of contamination-reinforcing the idea that national identity is based on purity (Cisneros 2008, p. 591) - menace, disease carriers (Esses and Medianu 2013), pollutants (Cisneros 2008), or invasion and terrorism (Chavez 2008; Haddad 2007; Mamadouh 2012; Lee, Charity Chin Ai. 2016). These images contribute to the knowledge construction of "outsiders" as a threat (Chavez 2008; Chavez 2001) and thus makes many states antagonistic towards refugees.

In addition to a discriminatory history of immigration law and media representations, immigrants and asylum-seekers continue to be conflated in popular discourse and from that moment on, foreigners of all kinds have been subject to close examination in the name of "security" (Hyndman and Mountz 2008, p. 249; Huysmans 2006). As Jennifer Hyndman (2007) argues elsewhere, security has been reconfigured in relation to citizenship, provoking a discursive shift from human rights toward human security. Discourses of securitisation are so powerful-particularly after the 9/11 terrorist attacks in the US-and the associated narratives so prevalent, that society makes the immediate connection between asylum-seekers and security concerns (Bigo 2002; Klocker and Dunn 2003; Kmak 2015; Mahtani and Mountz 2002; Zagor 2015). These representations and discourses are not exclusively deployed in Western countries. In Malaysia, for instance, refugees have been depicted either as problems or victims, each engendering a different response by the public and policy makers (Lee, Charity Chin Ai. 2016; Hoffstaedter 2017). The systematic process of othering refugees in this way corresponds to the state's efforts to categorise people based on their ethnic identity and usefulness 
to the national project of economic development. This process of knowledge construction, based on rhetoric, connects immigrants to securitisation, pollution, or even invasion, and has spilled over to asylum-seekers and refugees (Hoffstaedter 2017; Riva 2017). This way, governments pursue and justify measures to regulate the entrance of both migrants and refugees-given that they represent a threat to their territoriesmaking it hard for refugees to access their human rights. Additionally, securitisation narratives have justified the increase of bureaucratization and regularization of migration which has in turn justified the expansion of neoliberal policies creating a need for all types of non-state actors to enter the migration management regime as mediators. These actors have become brokers between the refugee and the state.

Brokers play a very important and vital role within the global refugee regime (Tuckett 2018, p. 246). Academic literature has explored examples of solidaristic interaction between refugees and non-refugees (Hayden and Saunders 2019), as well as the obstacles faced by populations trying to access refugee status; for instance, Karamanidou and Schuster (2011) discuss the difficulties refugees encounter when trying to access the asylum-seeking process in the European context. Similarly, Taylor and Rafferty-Brown (2010) analyse the difficulties asylum-seekers in Indonesia experience in obtaining access in their refugee status determination process and make recommendations to mitigate the difficulties identified, while Antje Missbach (2015) focuses on the complexities of transit migration in Indonesia from the perspective of the migrants before they arrive in Australia. Similarly, Gregor Noll (2010) addresses the barriers faced by undocumented immigrants accessing human rights, however, Noll deals exclusively with workers already living in the state territory and jurisdiction. While most of these very insightful accounts mention the organisations that help refugees, they rarely focus on the function these brokers play within the asylum-seeking process. Brokers-understood as mediators-have become key actors helping refugees gain their legal status. Some authors argue that despite how demonized these players are today, brokers are key for migrants to access certain institutions-work, marriage, education, and so on (McKeown 2012). Heath Cabot (2013) examines the crucial role of non-profit organisations in producing and coproducing eligible aid candidates in Greece. In this piece, she devotes most of her attention to how refugees interact within the structure of the broker-in this case, the NGO. She reveals how some refugees exercise forms of agency by refusing to engage in the established notion of victimhood for this population. Thomas Bierschenk et al. (2002) examine the role of development brokers in West Africa, how these mediate between donors and potential beneficiaries of development aid. These authors go beyond the negative connotation of brokers as taking advantage of the local population to focus on local power configurations and how these enable the rise of brokers.

Following the call by Mosse and Lewis (2006), we examine brokerage through an ethnographical analysis. Brokerage is no longer understood as the result of a weak state, but rather, as the result of the state's retreat and abandonment of its responsibilities. Neoliberal governance has increased the space for non-state actors to fill this void left by the state. These non-state actors end up performing the tasks that governments either previously have or should have carried out. By focusing on the brokers who help people access their refugee status, we seek to build on the empirical work of other authors (Bierschenk et al. 2002) who have already pointed out the potential of brokers to 
gain insight into our social reality. We claim that brokers have become key actors for refugees to access the legal process for obtaining status. Adding to what other researchers have described (Lindquist et al. 2012), we include in the definition of brokers a range of non-profit organisations, including international organisations. In our case: legal advocates, volunteers, NGOs, CSOs and other mediating agents both in Malaysia and the USA. In contrast to studies that emphasize deterritorialisation tendencies (for instance, Sassen 1999), we aim to ground refugees' experiences to particular locations. By drawing on comparative ethnographic research conducted in the United States and Malaysia we seek to contribute to the existing literature on brokers by demonstrating the difficulties refugees face in accessing their rights, and pointing out how they become the centre of the aporia.

\section{The US-Mexico border: the detention Centre}

The United States of America is signatory to the 1967 Protocol to the Refugee Convention. As such, it is obliged not to send or return refugees to locations where they might be persecuted in line with the non-refoulement principle. Refugees who cross the Southern border are predominantly from the Northern Triangle: Guatemala, Honduras, and El Salvador. They flee from the violence that is taking place in their home countries and arrive on foot in the US, a country they perceive as a safe haven. The vast majority of the people who arrive through the Southern border hire a coyote-smuggler-to help them enter the country. ${ }^{3}$ The price people need to pay a coyote to travel from El Salvador to the US can range between US $\$ 5000$ to US $\$ 14,000$ (Kulish 2018). Once they reach the border, many are confined in US temporary holding cells where they endure different forms of punishment (Riva 2017). They are later transferred to immigration detention centres where they are held until they pass their Credible Fear Interview-or asylum interview - with an asylum officer. The outcome of this interview will determine whether they can stay in the US and start the legal process of becoming a refugee, or whether they will be deported back to their country of origin.

Elena ${ }^{4}$ and her three children reached the United States with the help of a coyote after a month of traveling from El Salvador. For the last two years she had been threatened and extorted by the local gangs also known as maras. ${ }^{5}$ Elena is a single mother, owner of a small stall at a local market in El Salvador. Her modest income barely allowed her to take care of her three children when the economic extortion started. Before leaving for the US, Elena was approached once a week by gang members to collect money from her, commonly known as "the rent". Maras fund their activities-buying weapons, supporting jailed members, running the organisation-through the extortion of citizens. It is estimated that the local population pays US\$756 millions per year to the maras to avoid being killed (Robbins 2018). Elena tried to make the gang members understand that she could not keep up with the payments with what she earned, but they threatened to kill her and her children if she did not pay. She tried moving houses and moving her shop to another market but the gang members found her. A few weeks before she decided to leave the country, her son told her that he had been approached by members of a mara who had told him to join them if he wanted to survive. The way

${ }^{3}$ For more on the experiences of migrants traveling see Vogt 2018.

${ }^{4}$ Composite story based on fieldwork interviews conducted at a US immigration detention centre.

${ }^{5}$ See Bruneau et al. 2011. 
gangs work is through the recruitment of young boys to perform extortions and other types of delinquent activities, and use young girls for sexual violence (O'Toole 2018). Elena realised that it was only a matter of time until her children were dragged into extreme levels of violence. The experience of deep economic oppression combined with the fear for their children's futures, led Elena to decide that the only option she had was to flee to a safer country. ${ }^{6}$

Once they entered the US by foot, United States Border Patrol officers apprehended Elena and her children and put them in a temporary holding cell for three days. Wet from crossing the river that separates Mexico from the US and cold from the low temperatures at the holding cell, Elena's youngest daughter fell sick. All of Elena's belongings had been thrown away by US officials and thus they did not have a dry change of clothes. Later, they were transferred to a family immigration detention centre in the state of Texas where she and her children were held for three weeks until Elena got the results from her asylum interview. Family detention centres are for women and their underage children.

In the detention centre, Elena was lucky to meet a non-profit organisation that works with detained women. This is not a common occurrence in the United States. In most detention centres people who seek asylum do not receive guidance in their asylum process in any way. In this particular detention centre the organisation not only accompanies detainees through the whole asylum process, but they also do it in their language-most often Spanish but occasionally in other languages. This NGO helped her understand the process she had to go through to be able to enter, and then stay, in the United States. "The first thing we ask in the first charla [talk] we give is 'do you know what asylum is?' and a few of them know it means some sort of protection, but most of them don't. So, what we do in this first charla is explain the whole process they're going to go through" Inés (pseudonym), a legal advocate working for the non-profit organisation in the detention centre, explained in an interview. Among other things, legal advocates from this organisation made clear to her the steps she had to take to apply for asylum, prepared her for her asylum-interview, informed her that in order to leave the detention centre she had to choose between paying a bond that ranged between US $\$ 2000$ and US $\$ 8000$ or wearing an ankle monitor, and acted as advocates on her behalf during the time she and her children were held in the detention centre. Another legal advocate commented: "It is a very complicated process, even for us! Can you imagine going to another country without speaking the language and having to deal with all this! We just try to prepare them as best as we can for what's coming and try to make sure they attend their court hearings once they leave [the detention centre]". In this way, these advocates not only acknowledge the complexity of the asylum-seeking process that these women need to go through but try to guide them through it by advising them about the future steps they will need to take once they leave the detention facility.

While detained, Elena's daughter remained sick due to the constant low temperatures in the centre. Legal advocates helped Elena with her daughter's lack of proper medical attention as well as with other issues-such as getting her son a new pair of glasses as

${ }^{6}$ Elena's case is an illustrative example of the story of thousands of women who try to cross the US-Mexico border every year. 
his had broken while in detention. Inés recounted: "Sometimes we need to talk to the people here [in the detention centre]. For instance, to make sure they [the guards] still have their [the women's] belongings from when they first got here. Some women get anxious about their stuff. Many have medical evidence of the violence they experienced in their country. Or sometimes if they have a medical condition, or if their children are not doing well".

In regard to her asylum interview, legal advocates in the detention centre helped Elena understand what was expected of her. ${ }^{7}$ In this interview, the asylum claimant has to explain the reasons for leaving her country, she has to prove that her fear is credible, and needs to demonstrate that her story fits into one of the five nexuses of persecution that exist within the Refugee Convention in regard to asylum: race, religion, nationality, political opinion, and member of a particular social group. "Most women tell their story like ... in a disorganised manner ... it's hard to explain ... everything is mixed up in their heads. They go through horrific stuff and I guess it's hard to organise it in one's head, let alone tell a stranger," Linda (pseudonym), an advocate working at the centre, explained. The asylum-interview is a combination of storytelling and performance of proper citizenship, in the sense that the story is just as important as how she tells it (see, for example, Blommaert 2001, Coutin 2000, Jeffers 2012, Khosravi 2010, Shuman and Bohmer 2004, Woolley 2017). Elena has to be able to tell the story using Western standards-narrating in a very clear and linear manner, presenting an account of the facts in chronological order, and showing emotion whenever the story requires it. In addition, she has to prove that she is a responsible mother who will take care of her children, find a job, and fit into the hosting country. Research shows that countries tend to favour asylum claimants who will potentially assimilate better (Valji 2001, p. 28).

Legal advocates spend a considerable amount of one on one time with each woman helping her prepare for the asylum-interview. "We tell the women to tell us their story and then we go through it again and say things like, 'what happened first, what happened after, what was the worst thing that happened to you', and things like that, so it makes sense. We also tell them it's important not to lie or mention dates if they are not pretty ... no! absolutely sure that things happened on that day" Alma (pseudonym) explained. Legal advocates coach the women on how to tell their story in a way that makes sense for the Western listener, encourage them to be clear about when and how the instances of violence took place, and explain to them the importance of a precise description of some of those moments. The 1951 Convention's official definition of a refugee is based on political acts occurring in the public sphere among public actors (Cianciarulo 2012, p. 139), and thus in the asylum-interview detainees' narratives need to connect the violence they have personally experienced to the broader system, in other words, to the state. They need to prove that their experiences are not "individual violence", otherwise they will not qualify for asylum. However, this narrative is necessarily disconnected from any US responsibility in the creation, sustenance, and growth of that violence-i.e. the creation of the maras in L.A. prisons in the 1980s, decades of military intervention in the region, and the impact of the war on drugs (Valdez 2011). As a result, there is a presentation of the US as a benevolent, meritocratic society in

${ }^{7}$ For more information on the work of legal advocates in detention centres see Riva and Routon (2020). 
contrast to countries from the Northern Triangle, which are classified as violent spaces and/or unjust societies. The way the refugee procedure is set up reinforces the US humanitarian credentials.

The presence of legal advocates in the detention centre is paramount for the women to be able to manoeuvre the immigration system more generally. By coaching Elena for her asylum-interview, they make her aware of what the US government expects from her. This does not mean that Elena is a mere victim of the system; the coaching makes her understand what is expected of her and how she can engage in it to reach her objective: pass her asylum-interview so she and her children can stay in the US. Thus, the legal NGO becomes a key broker in the US asylum-seeking process. This non-profit organisation acts as a broker between those who seek asylum and the state. According to data, when a legal representative is involved in a case the chances of gaining asylum are five times higher than when people are on their own (Conlon 2019, p. 391). The United States is obliged to analyse each case individually and make sure that no person is returned to a place where their life is in danger. However, without the presence of this NGO, which does not receive funding from the government, the US state's probability of failing to comply with its international responsibility increases significantly. This situation has repeatedly been exposed by activist groups, humanitarian workers, and the media, however the US has not done anything to remedy the lack of access to legal aid for refugees. This absence of concern on behalf of the authorities illustrates that the United States has abrogated some responsibilities to non-profit organisations like the one profiled here. This is one of many barriers people seeking asylum in the US face in order to access their rights.

\section{Malaysia: community self-protection in a legal vacuum}

Malaysia, on the other hand, is not even a signatory to the UN refugee convention and refugee status is not formally recognised by the Malaysian state. The UNHCR maintains a busy office in Kuala Lumpur, where it registers refugees, issues UNHCR registration cards, which afford a modicum of protection from police and immigration harassment, and advocates for refugees more generally. Refugees, who have fled to Malaysia, generally perceive it to be a safe place for first asylum or transit. Whilst refugees are subject to arbitrary arrest and detention in Malaysia's notorious detention centres (Ananthalakshmi 2017), they are also able to work in Malaysia's vast shadow economy, which usually allows them to remit monies to their family and friends elsewhere.

Refugees in Malaysia are predominantly from Myanmar and enter the country via smuggling and trafficking routes from Thailand over land or via the sea. Once they arrive, they make their way to the major cities, where families and friends await their arrival. These journeys are fraught with danger: sometimes smugglers abandon people, imprison and ransom them, or simply dispose of them. In 2015 several camps used by traffickers and smugglers were discovered alongside shallow graves and prison like huts along the Thai-Malaysian border (SUHAKAM, and Fortify Rights 2019). Thus, whilst Malaysia is not be a signatory to the refugee convention, it nonetheless has been a place of refuge for hundreds of thousands of refugees from Myanmar and elsewhere. Lax visa restrictions make entry relatively easy for some, whilst others rely on porous borderlands and corrupt immigration officials to allow for passage to a better life and some 
protection. Once arrived, refugees have to make their way to the UNHCR compound in the centre of Kuala Lumpur to register with the only authorities able and willing to provide refugees with some sort of bureaucratic proof of identity. The UNHCR is also the only place that can offer refugees hope for a future elsewhere through their resettlement program. However, due to the high numbers of refugees from Myanmar registration has been halted periodically and some refugees have not been allowed to approach the UNHCR directly. Rather, they have to register with community refugee organisations who forward lists to the UNHCR for processing and the arrangement of interviews for status determination. Many of these CROs were set up to support the UNHCR and shifted responsibility and management of refugee data collection to the communities themselves. Some were set up with the help of international civil society actors, and all are now run and managed by refugees themselves with no external oversight.

Ahmed, ${ }^{8}$ a Rohingya refugee from Rakhine state in Myanmar had fled decades of persecution there that keeps Rohingya in poverty and excluded from education. Several recent outbreaks of violence had led to acts of genocide against the Rohingya, forcing many to flee the country. His journey started as part of a smuggling operation to take him to Malaysia. However, as is the case for many people who begin journeys as part of a smuggling operation, his turned into one of human trafficking. Once he reached Thailand he was separated from his friends, shackled and imprisoned in a rudimentary bamboo jail in a human trafficking camp in the jungle. He was moved several times until he was in a camp in Malaysia (unbeknownst to him). He was forced to call one of his uncles to secure more money for his release. Unable to pay, Ahmed managed to escape the trafficking camp in Malaysia and make it to Kuala Lumpur safely. Ahmed was shaken, but also relieved to have finally made it to safety in a Muslim majority country like Malaysia after years of discrimination and violence against his Rohingya people in Myanmar. However, the journey to gain refugee status had only just begun for him. With the help of his uncle, Ahmed quickly found a job cutting grass for a contractor who was also Rohingya. The pay was meagre but allowed him to pay for a bed in a shared room in an overcrowded apartment and pay for his food and medical bills-he had become sick on the journey to Malaysia and required frequent medical check-ups and medicine for his stomach. Like most Rohingya refugees, he went to a local Malay doctor who charged him the regular rates, because he took pity on Rohingya living a tough life in Malaysia.

The UNHCR is merely tolerated by the Malaysian state and the level of protection it offers is limited to issuing an official UNHCR identity card after status determination is complete that provides basic protection for refugees. The UNHCR does not provide any subsistence, health or social welfare to refugees. Some CROs and local NGOs provide limited services, but most refugees have to fend for themselves (Hoffstaedter 2015b). As a result, most Rohingya quickly pick up the Malay language, find work to sustain themselves and try to blend in as best they can. This is important because any police stop could mean their immediate detention in overcrowded and underresourced immigration detention camps and/or the demand of substantial bribes.

${ }^{8}$ Ahmed is a pseudonym and composite identity representative of the refugee experience of the majority of Rohingya, the largest refugee group to be registered as persons of concern by the UNHCR in Malaysia. 
Ahmed's uncle urged him to join a local Rohingya community refugee organisation, which could help him get registered with the UNHCR. However, Ahmed had heard that many such organisations exist and not all are there to help refugees. He wanted to find another way to register. After several attempts, he contacted someone who told him he could get him a registration card for a fee; all he needed was a passport picture and 2000RM (US\$500). Ahmed had just begun to repay the loans needed to escape Myanmar but was able to secure new loans in Malaysia for the documents. He paid the agent and waited to receive word when the documents would be finished. He never heard back from the agent. Now, owing even more money, he redoubled his efforts to find another job to pay for his loans and registered with all the Rohingya refugee community organisations he could find. Registration, again, involves a charge, usually a yearly membership fee to register with the $\mathrm{CRO}$ and obtain a registration card. Most CROs offer this service. One benefit is that the CRO card looks official and might be enough to escape a police control. Some CROs offer an added service of intervention, if a refugee is arrested, for instance. Then, the police officer can call the number on the CRO card and speak to an official from the refugee organisation. Usually this official will then negotiate the release of the refugee with the police officer. Thus, some CROs act as brokers for protection services in the absence of UNHCR protection or in addition thereof. However, the main benefit of joining a CRO is that they are supposed to forward the contact details for each refugee they register to the UNHCR for processing.

It usually takes several years for refugees in Malaysia to go through official status determination and be recognized as a refugee by the UNHCR. Ahmed was called in for an interview after waiting three years, living and working in Kuala Lumpur and paying occasional bribes to police to stay out of immigration detention. His membership in the largest and only Rohingya CRO recognized by the UNHCR had paid off as they had forwarded his details to the UNHCR for processing. When he was called up by an UNHCR registration officer, he could not believe it at first and it took a while to sink in that he soon would be in possession of the UNHCR refugee card. In order to be registered, the UNHCR in Malaysia has trialled several different methods, including mass registration drives (sometimes conducted at stadiums) and mobile registrations (where UNHCR officers register refugees across the country, working with local refugee community organisations). The interviews conducted vary considerably in length and depth of the questioning. At present, it is sufficient for Rohingya to prove they are Rohingya to qualify for refugee status; they do not require specific stories of discrimination and persecution as per the refugee convention definition. However, few Rohingya have documents, either because they never received any from the Myanmar state, fled without them, or because smugglers told them to throw them overboard on the journey. Thus, proving who they are and where they are from can be very difficult. Alongside checking the veracity of their status as Rohingya, registration officers deploy tools such as checking the consistency of stories told to them by re-interviewing applicants. This process is complicated by the constant need for translators, most of whom are recruited from the refugee communities themselves and many of whom change frequently. This makes the presentation of a consistent story of persecution in Myanmar, flight and arrival in Malaysia extremely difficult. The lack of highly trained translators and the reliance on their translation for every aspect of the refugee status determination process 
problematizes their powerful role in the mediation of claims, truth and identity verification. Ahmad cannot speak English and therefore never knew whether his translators correctly translated his story, but after two interviews he was granted refugee status and the new biometric refugee identity card. This recognition of an identity as both Rohingya and refugee by an international organisation meant the world to him and could not have happened without the intercession and brokerage of the CRO who is a de facto implementing partner for the UNHCR and provides a vital service in registration and administration of key personal data of people seeking to apply for refugee status in Malaysia.

\section{Brokerage between refugees and the state}

The 1951 Refugee Convention was written after WWII to provide a universal definition of those who did not have the protection of any government and to grant them international legal protection. Over the last decades, many scholars have deployed critiques of the Refugee Convention, with particular emphasis in feminist scholarship on the topic (Edwards 2010; Freedman 2010; Greatbatch 1989; Pickering 2005; Tvedt 2013; Valji 2001). As any historically situated document-demonstrated by article 1-the Refugee Convention was based on what at that time were European concerns with European refugees; namely, Western, upper-middle class, educated white men. At the time, many of the people fleeing from violence were welcomed in receiving countries because it helped situate these nation-states in opposition to authoritarian regimes-especially communist ones-and as defenders of freedom (Chimni 1998). Despite major historical and political changes, such as the falling of the Soviet bloc, the war in Syria or climate induced displacement, the Refugee Convention and its Protocol have not changed to better reflect modern displacements and its concomitant population movements.

Even though the state and international organisations are responsible for people who seek asylum, in today's international protection regime people like Elena and Ahmed who do not fit the mould of a white European male refugee require the assistance of third-party organisations and brokers to access their refugee rights. This is coupled with a growth of neoliberal policies that enabled the insertion of private actors in the public arena more generally. In the asylum regimes this has meant a withdrawal of government or institutional support for claimants. This in turn necessitated the interventions of brokers to safeguard access to rights for these claimants. Thus, the role the non-profit organisations described in this paper play in the refugee regime is key for asylum claimants. Without these brokers, seeking asylum and access to refugee rights may not be possible at all. In Elena's case we can see that she did not know what "asylum" was until she met the legal advocates at the detention centre who made her aware of her rights. She had to be coached to shape her story into one that fits in an androcentric outdated Refugee Convention framework. In Ahmed's case, without the CRO his details would never have been forwarded to the UNHCR for registration. When there are no organisations to help refugees, they may be left vulnerable and unaware of their rights. However, we must also be wary of the way some humanitarian organisations can act against refugee needs by engaging in corruption, partiality or unaccountability (Redvers 2015). The need for good brokers is especially felt by those refugees, who are further disadvantaged by being physically detained in detention centres, away 
from access to advocacy, community and services. Both case studies demonstrate that refugees face different barriers to accessing their rights; and how, in both cases NGOs and CROs were crucial brokers in shaping the pathways for refugees to access their rights.

The US case demonstrates that access to territory is only the first step in a process where a fair hearing of asylum claims is the new battleground between those intent on diminishing international obligations and those trying to uphold them. The Malaysian case shows that access to territory means even less in countries that are nonsignatories to international rights regimes and, here, access to said regimes is often mediated by third parties with differing agendas. Navigating this complex process to obtain access to human rights is becoming harder and harder. This is no accident as states reassert their sovereignty through enacting border regimes inconsistent with the spirit of the international human rights regime, but consistent with national statemaking processes, so adroitly described by Arendt seventy years ago.

\section{Conclusions}

In this paper, we have sought to contribute to the literature on brokerage by highlighting the importance of these actors within the refugee regime, in particular, when refugees seek to access their rights. We claim that the study of brokers is relevant for three reasons. First, as Johan Lindquist and others (2012) have already pointed out, scrutinizing brokerage illuminates how certain types of mobility are made possible. In our case, we demonstrate how refugees require brokers to gain legal access to the refugee registration regime. Without these mediators, refugees have few or no ways to access their rights. Additionally, as we have shown, NGOs, CROs, and the UNHCR all carry out instrumental work in the refugee registration process and many of these organisations are closely working with governments. The exercise of brokerage thus blurs distinctions between non-profit work, international organisations, government work, and other types of brokers (Lindquist et al. 2012). Brokers have become key actors to help refugees access international norms and rights.

Second, the study of brokerage highlights how neoliberalism, or the "rolling back" of the state, has created significant gaps that have made these mediators relevant within different structures, including that of state power. Neoliberalism and its impulse to incorporate private actors in migration management, including detention and removal (Menz 2011, 2013), have pushed many of these organisations to carry out the work that the state or international organisations like the UNHCR should be doing. The neoliberal modus operandi is to transfer public functions to private actors (Pyles 2009). Thus, in the US case, the presence of a private non-profit organisation in a privatized detention facility demonstrates that private actors are handling public issues. In Malaysia, meanwhile, without CRO brokers refugees from Myanmar have no way to access the UNHCR and its refugee registration regime, making the brokerage indispensable. Therefore, without brokers most refugees are unable to access their rights, making these mediators integral to new forms of neoliberal governance of migration and protection (Darling 2016; Lindquist et al. 2012).

Lastly, Arendt's aporia, or "perplexities of the rights of man", was premised on the lack of inalienable human rights regardless of ones' national citizenship. The international community seemingly addressed this aporia with many specific human rights 
instruments that address statelessness and refugees, such as the Refugee Convention and Protocol, the Convention on the Rights of the Child (CRC), the Convention on the Elimination of all Forms of Discrimination Against Women (CEDAW), the Convention Against Torture and Other Cruel, Inhuman or Degrading Treatment or Punishment (CAT). However, the weak enforcement, pointed out by Arendt (1979) so long ago, persists as we have shown using two very different ethnographic case studies. In addition, in order to access these inalienable rights now afforded every human being, new obstacles and barriers have to be surmounted. The mere fact of the existence of rights has done little to allow people in need of protection to access them in a timely, direct and straightforward way. Claiming rights, thus, becomes an exercise in seeking access to organisations who in turn are willing and able to procure access to these inalienable human rights. Therefore, the tensions and contradictions persist in the way rights are accessed and available to those outside of national rights afforded citizens and legal residents.

Authors' contributions

We are the sole authors of this publication. The authors read and approved the final manuscript.

\section{Funding}

Dr. Riva received funding from the European Union's Horizon 2020 research and innovation programme under the Marie Skłodowska-Curie grant agreement No 839191. Dr. Hofstaedter received a Discovery Early Career Researcher Award (project number DE140100052) funded by the Australian Research Council.

Availability of data and materials

Data sharing is not applicable to this article as no datasets were generated or analysed during the current study.

\section{Ethics approval and consent to participate}

This research passed ethics approval and consent from individual participants.

The Ohio State University. Ethics approval number: $2016 \mathrm{~B} 0187$.

University of Queensland Ethics Approval No. 2015000349.

To protect the identity and safety of interview subjects, research data are not shared.

Competing interests

There are no competing interests in this article.

\section{Author details}

${ }^{1}$ Marie Skłodowska-Curie Research Fellow, Spanish Research Council (CSIC), Madrid, Spain. ${ }^{2}$ The University of Queensland, St Lucia QLD 4072, Australia.

Received: 13 July 2020 Accepted: 2 November 2020

Published online: 22 January 2021

\section{References}

Ananthalakshmi, A. (2017). Malaysia rights panel disturbed over more than 600 deaths in prisons and detention centers. Reuters. Arendt, H. (1979). The Origins of Totalitarism. New York: Harvest Book. Original edition, 1951.

Bierschenk, T., Chauveau, J.-P., De Sardan, J.-P. O., \& Kossi, A. (2002). Local development brokers in Africa. The rise of a new social category (Working Papers Nr. 13). Mainz: Institut für Ethnologie und Afrikastudien, Johannes Gutenberg-Universität.

Bigo, D. (2002). Security and immigration: Toward a critique of the governmentality of unease. Alternatives, 27(1), 63-92.

Blommaert (2001). Investigating narrative inequality: African asylum seekers' stories in Belgium. Discourse \& Society, 12(4), 413-449.

Bruneau, T., Dammert, L., \& Skinner, E. (2011). Maras: Gang violence and security in Central America. Austin: University of Texas Press.

Cabot, H. (2013). The social aesthetics of eligibility: NGO aid and indeterminacy in the Greek asylum process. American Ethnologist, 40(3), 452-466.

Chavez, L. (2008). The Latino threat: Constructing immigrants, citizens, and the nation. Standford: Stanford University Press.

Chavez, L. R. (2001). Covering immigration: Popular images and the politics of the nation. Berkeley: University of California Press.

Chimni, B. S. (1998). The geopolitics of refugee studies: A view from the south. Journal of Refugee Studies, 11(4), 350-374. https://doi.org/10.1093/jrs/11.4.350-a.

Cianciarulo, M. S. (2012). Batterers as agents of the state: Challenging the public/private distinction in intimate partner violence-based asylum claims. Harvard Journal of Law \& Gender, 35, 117.

Cisneros, J. D. (2008). Contaminated communities: The metaphor of "immigrant as pollutant" in media representations of immigration. Rhetoric \& Public Affairs, 11(4), 569-601. 
Conlon, D. (2019). Contradictions and provocations of neoliberal governmentality in the US asylum seeking system. In K. Mitchell, R. Jones, \& J. L. Fluri (Eds.), Handbook on critical geographies of migration (pp. 384-396). Cheltenham; Northampton, MA: Edward Elgar.

Coutin, S. B. (2000). Legalizing moves: Salvadoran immigrants' struggle for U.S. residency. Ann Arbor: University of Michigan Press.

Coutin, S. B. (2007). Nations of Emigrants: Shifting Boundaries of Citizenship in El Salvador and the United States. Ithaca: Cornell University Press.

Darling, J. (2016). Privatising asylum: Neoliberalisation, depoliticisation and the governance of forced migration. Transactions of the Institute of British Geographers, 41(3), 230-243.

Edwards, A. (2010). Transitioning gender: Feminist engagement with international refugee law and policy 1950-2010. Refugee Survey Quarterly, 29(2), 21-45.

Esses, V. M., Medianu, S., \& Lawson, A. S. (2013). Uncertainty, threat, and the role of the media in promoting the dehumanization of immigrants and refugees. Journal of Social Issues, 69(3), 518-536.

Freedman, J. (2010). Mainstreaming gender in refugee protection. Cambridge Review of International Affairs, 23(4), 589-607.

Greatbatch, J. (1989). The gender difference: Feminist critiques of refugee discourse. International Journal of Refugee Law, 1(4), $518-527$.

Grewcock, M. (2013). Australia's ongoing border wars. Race \& Class, 54(3), 10-32.

Gündoğdu, A. (2012). 'Perplexities of the rights of man': Arendt on the aporias of human rights. European Journal of Political Theory, 11(1), 4-24.

Haddad, E. (2007). Danger happens at the border. In P. K. Rajaram, \& C. Grundy-Warr (Eds.), Borderscapes: Hidden geographies and politics at Territory's edge (pp. 119-136). Minneapolis: University of Minnesota Press.

Haraway, D. (1988). Situated knowledges: The science question in feminism and the privilege of partial perspective. Feminist Studies, 14(3), 575-599.

Hayden, P., \& Saunders, N. (2019). Solidarity at the margins: Arendt, refugees, and the inclusive politics of world-making. In K. Hiruta (Ed.), Arendt on freedom, liberation, and revolution (pp. 171-199). Basingstoke and New York: Palgrave Macmillan.

Hirsch, A. L., \& Bell, N. (2017). The right to have rights as a right to enter: Addressing a lacuna in the international refugee protection regime. Human Rights Review, 18(4), 417-437. https://doi.org/10.1007/s12142-017-0472-4.

Hoffstaedter, G. (2015a). Between a rock and a hard place: Urban refugees in a global context. In G. Hoffstaedter, \& K. Koizumi (Eds.), Urban refugees: Challenges in protection, services and policy (pp. 1-10). London: Routledge.

Hoffstaedter, G. (2015b). Urban refugees and the UNHCR in Kuala Lumpur: Dependency, assistance and survival. In G. Hoffstaedter, \& K. Koizumi (Eds.), Urban refugees: Challenges in protection, services and policy (pp. 187-205). London: Routledge.

Hoffstaedter, G. (2017). Dominant discourses of refugees, recognition, and othering in Malaysia. Situations: Cultural Studies in the Asian Context, 10(2), 27-44.

Huysmans, J. (2006). The politics of insecurity: Fear, migration and asylum in the EU. New York/London: Routledge.

Hyndman, J. (2007). The securitization of fear in post-tsunami Sri Lanka. Annals of the Association of American Geographers, 97(2), 361-372.

Hyndman, J., \& Mountz, A. (2008). Another brick in the wall? Neo-Refoulement and the externalization of asylum by Australia and Europe. Government and Opposition, 43(2), 249-269.

Jeffers, A. (2012). Refugees, theatre and crisis: Performing global identities. Basingstoke and New York: Springer.

Karamanidou, L., \& Schuster, L. (2011). Realizing one's rights under the 1951 convention 60 years on: A review of practical constraints on accessing protection in Europe. Journal of Refugee Studies, 25(2), 169-192.

Khosravi, S. (2010). 'Illegal' traveller: An auto-ethnography of borders. Basingstoke and New York: Palgrave Macmillan.

Klocker, N., \& Dunn, K. M. (2003). Who's driving the asylum debate? Newspaper and government representations of asylum seekers. Media International Australia Incorporating Culture and Policy, 109(1), 71-92.

Kmak, M. (2015). Between citizen and bogus asylum seeker: Management of migration in the EU through the technology of morality. Social Identities, 21(4), 395-409.

Kulish, N. (2018, June 30). What it costs to be smuggled across the U.S. border. The New York Times. https://www.nytimes. com/interactive/2018/06/30/world/smuggling-illegal-immigration-costs.html. Accessed 28 Apr 2019.

Lee, C. C. A. (2016). Refugee representation in Malaysia: A study of media representations and personal narratives. Ph. D Jabatan Bahasa Inggeris, Fakulti Bahasa dan Linguistik, Kuala Lumpur: Universiti Malaya.

Lindquist, J., Xiang, B., \& Yeoh, B. S. A. (2012). Opening the black box of migration: Brokers, the organization of transnational mobility and the changing political economy in Asia. Pacific Affairs, 85(1), 7-19.

Mahtani, M., \& Mountz, A. (2002). Immigration to British Columbia: Media representation and public opinion (Research on Immigration and Integration in the Metropolis Working Paper Series, No. 02-15). Vancouver: Vancouver Centre of Excellence.

Mamadouh, V. (2012). The scaling of the 'invasion': A geopolitics of immigration narratives in France and the Netherlands. Geopolitics, 17(2), 377-401.

McKeown, A. (2012). How the box became black: Brokers and the creation of the free migrant. Pacific Affairs, 85(1), 21-45.

Menz, G. (2011). Neo-liberalism, privatization and the outsourcing of migration management: A five-country comparison. Competition and Change, 15(2), 116-135.

Menz, G. (2013). The neoliberalized state and the growth of the migration industry. In The migration industry and the commercialization of international migration. London and New York: Routledge.

Missbach, A. (2015). Troubled transit: Asylum seekers stuck in Indonesia. ISEAS-Yusof Ishak Institute.

Mosse, D., \& Lewis, D. (2006). Theoretical approaches to brokerage and translation in development. In Development brokers and translators: The ethnography of aid and agencies, (pp. 1-26).

Noll, G. (2010). Why human rights fail to protect undocumented migrants. European Journal of Migration and Law, 12(2), 241-272.

O'Toole, M. (2018, March 4). El Salvador's gangs are targeting young girls. The Atlantic. https://www.theatlantic.com/ international/archive/2018/03/el-salvador-women-gangs-ms-13-trump-violence/554804/. Accessed 2 May 2018. 
Pickering, S. (2005). Crimes of the state: The persecution and protection of refugees. Critical Criminology, 13(2), $141-163$.

Pyles, L. (2009). Neoliberalism, INGO practices and sustainable disaster recovery: A post-Katrina case study. Community Development Journal, 46(2), 168-180.

Redvers, L. (2015, March 5). What Refugees Really Think of Aid Agencies. The New Humanitarian. http://www. thenewhumanitarian.org/analysis/2015/03/05/what-refugees-really-think-aid-agencies.

Riva, S. (2017). Across the border and into the cold: Hieleras and the punishment of asylum-seeking central American women in the United States. Citizenship Studies, 21(3), 309-326.

Riva, S., \& Routon, E. (2020). Reinforcing and contesting neoliberal citizenship: Legal advocates and the asylum interview at the US-Mexico border. Journal of Refugee Studies, feaa066. https://doi.org/10.1093/jrs/feaa066.

Robbins, S. (2018, October 30). 3 crime factors driving northern triangle migrants out. InSight Crime. https://www.insightcrime. org/news/analysis/crime-factors-pushing-northern-triangle-migrants-out/. Accessed 1 May 2019.

Sassen, S. (1999). Globalization and its discontents: Essays on the new mobility of people and money. New York: The New Press.

Shuman, A., \& Bohmer, C. (2004). Representing trauma: Political asylum narrative. Journal of American Folklore, 117(466), 394-414.

SUHAKAM, and Fortify Rights (2019). 'Sold like fish': Crimes against humanity, mass graves, and human trafficking from Myanmar and Bangladesh to Malaysia from 2012 to 2015.

Taylor, S., \& Rafferty-Brown, B. (2010). Difficult journeys: Accessing refugee protection in Indonesia. Monash University Law Review, 36, 138

Tuckett, A. (2018). Ethical brokerage and self-fashioning in Italian immigration bureaucracy. Critique of Anthropology, 38(3), 245-264.

Tvedt, J. N. (2013). Accounting for gender in international refugee law: A close Reading of the UNHCR gender guidelines and the discursive construction of gender as an identity (Master of Arts in International studies (MAIS)). University of San Francisco.

Valdez, A. (2011). The origins of southern California Latino gangs. In T. Bruneau, L. Dammert, \& E. Skinner (Eds.), Maras: Gang violence and security in Central America (pp. 23-42). Austin: University of Texas Press.

Valji, N. (2001). Women and the 1951 refugee convention: Fifty years of seeking visibility. Refuge: Canada's Journal on Refugees, 19(5), 25-35.

Vogt, W. A. (2018). Lives in transit: Violence and intimacy on the migrant journey (Vol. 42: California Series in Public Anthropology). Oakland: University of California Press.

Woolley, A. (2017). Narrating the "asylum story": Between literary and legal storytelling. Interventions, 19(3), 376-394.

Xenos, N. (1993). Refugees: The modern political condition. Alternatives, 18(4), 419-430.

Zagor, M. (2015). The struggle of autonomy and authenticity: Framing the savage refugee. Social Identities, 21(4), 373-394.

\section{Publisher's Note}

Springer Nature remains neutral with regard to jurisdictional claims in published maps and institutional affiliations.

\section{Submit your manuscript to a SpringerOpen ${ }^{\circ}$ journal and benefit from:}

- Convenient online submission

- Rigorous peer review

- Open access: articles freely available online

High visibility within the field

- Retaining the copyright to your article

Submit your next manuscript at $\boldsymbol{\nabla}$ springeropen.com 